\title{
Biodiversity of Parasitic Copepods in Katsuwonus pelamis From Rio Grande do Norte Coast (NE Brazil)
}

\author{
Erivaldo Laurindo Gomes ${ }^{1}$, Cláudio Giovanio da Silva ${ }^{2 *}$, Naibe Cristina de Figueiredo ${ }^{1}$ and José Ticiano Arruda \\ Ximenes de Lima ${ }^{3}$ \\ ${ }^{1}$ Pós-graduação em Produção Animal, Centro de Ciências Agrárias, Universidade Federal Rural do Semi-Árido, Brasil \\ ${ }^{2}$ Laboratório de Sanidade Aquática, Centro de Ciências Agrárias. Universidade Federal Rural do Semi-Árido, Brasil \\ ${ }^{3}$ Professor do Curso de Engenharia de Pesca, Centro de Ciências Agrárias. Universidade Federal Rural do Semi-Árido, Brasil
}

Submission: January 26, 2018; Published: February 08, 2018

*Corresponding author: Cláudio Giovanio da Silva, Laboratório de Sanidade Aquática, Centro de Ciências Agrárias, Universidade Federal Rural do Semi-Árido, Rio Grande do Norte, Brasil, Tel: +55-88994901374; E-mail: giovaniosl@bol.com.br

\begin{abstract}
Ictioparasitology is a science that has, among its objectives, assisted in the understanding of the interactions between fish and their parasites. Crustaceans are one of the most popular invertebrate groups exhibit a striking diversity of forms, habits and sizes, are found at all depths in the various marine and freshwater of the earth, and Copepod class are the largest group crustacean parasites in fish, with economic importance, which may result in high mortality. In the present work the biodiversity of the parasitic copepods of skipjack tuna (Katsuwonus pelamis) from the Southwest Atlantic Ocean - Rio Grande do Norte, Brazil, is reported. Parasitic ecological indexes (prevalence, mean intensity and mean abundance) were also calculated. Fish were collected in the coastal area of Areia Branca (state of Rio Grande do Norte) from 2015 to 2016. Standard biometrics of the hosts was also taken. Four species were identified infecting branchial chamber and body skin of K. pelamis.: Caligus pelamydis (17.65\%), C. bonito (36.27\%), C. productus (37.25\%) and Pseudocycnus appendiculatus (8.82\%).
\end{abstract}

Keywords: Copepods; Parasitized fish; Parasitic ecological indexes; Parasitic Biodiversity

\section{Introduction}

The ictioparasitology is a science that has, among its objectives, assisted in the understanding of the interactions between fish and their parasites. The parasitism is the most common style of life on earth, as there are numerous representatives of permanent or temporarily zoological groups involved in interspecific relationship [1,2].

With regard to marine environments, Luque [3] considers that the knowledge about the diversity of species of parasites is still incipient front of the large ichthyological diversity. According to Pavanelli \& Takemoto [4] the parasite identification studies are important to know possible pathologies occurring in their hosts. Usually the damage to the host by parasitic diseases is related to the parasite species, its form of feeding, organ or tissue of an affected host, parasitism intensity and general condition of the host $[5,6]$.

The crustaceans are one of the most popular invertebrate groups exhibit a striking diversity of forms, habits and sizes, are found at all depths in the various marine and freshwater of the earth [7]. The parasitic crustaceans are highly modified organisms and oral swimming appendages have turned into powerful fasteners to the host, with consequent repercussions pathogenic [3]. The main groups comprising fish parasites are Copepods, Branchiura and Isopoda [8].

Copepods are the largest group crustacean parasites in fish, with more than 1,900 known species. Many species have economic importance especially when parasitize cultured fish, which may result in high mortality. All copepods have a postembryonic development that usually goes through three stages: nauplius, copepodite and adult [9].

The skipjack tuna Katsuwonus pelamis (Linnaeus, 1758; Osteichthyes: Scombridae) is an opportunistic predator that inhabits the tropical and warm temperate waters of all oceans. The range of this fish in the Atlantic Ocean is from $40{ }^{\circ} \mathrm{N}$ to 32 ${ }^{\circ} \mathrm{S}$, from the surface to about $260 \mathrm{~m}$ depth. Its distribution is influenced by water temperature (optimum range from 15 to 30 ${ }^{\circ} \mathrm{C}$ ). The skipjack tuna spawns when the surface temperature is $\geq 24{ }^{\circ} \mathrm{C}$, and its spawning season varies according to locality [10]. 
This study aimed to evaluate the parasites copepods biodiversity in the host skipjack tuna (K. pelamis) from the Southwest Atlantic Ocean - Rio Grande do Norte, Brazil.

\section{Material and Methods}

Located in the northeast of Brazil, the coastal region of Rio Grande do Norte (Figure 1) has humid tropical climate hot, with rains in the Summer (December to March) and dry conditions in Spring, Winter and Autumn (April to November), with an annual mean of $823 \mathrm{~mm}$ of rain and $32{ }^{\circ} \mathrm{C}$ air temperature [11]. The fish were acquired from fishermen in coastal area of Areia Branca, state of Rio Grande do Norte. Catches fish were carried out between the months of December/2015 to November/2016. The fish samples were carried out with the help fishermen in the region.

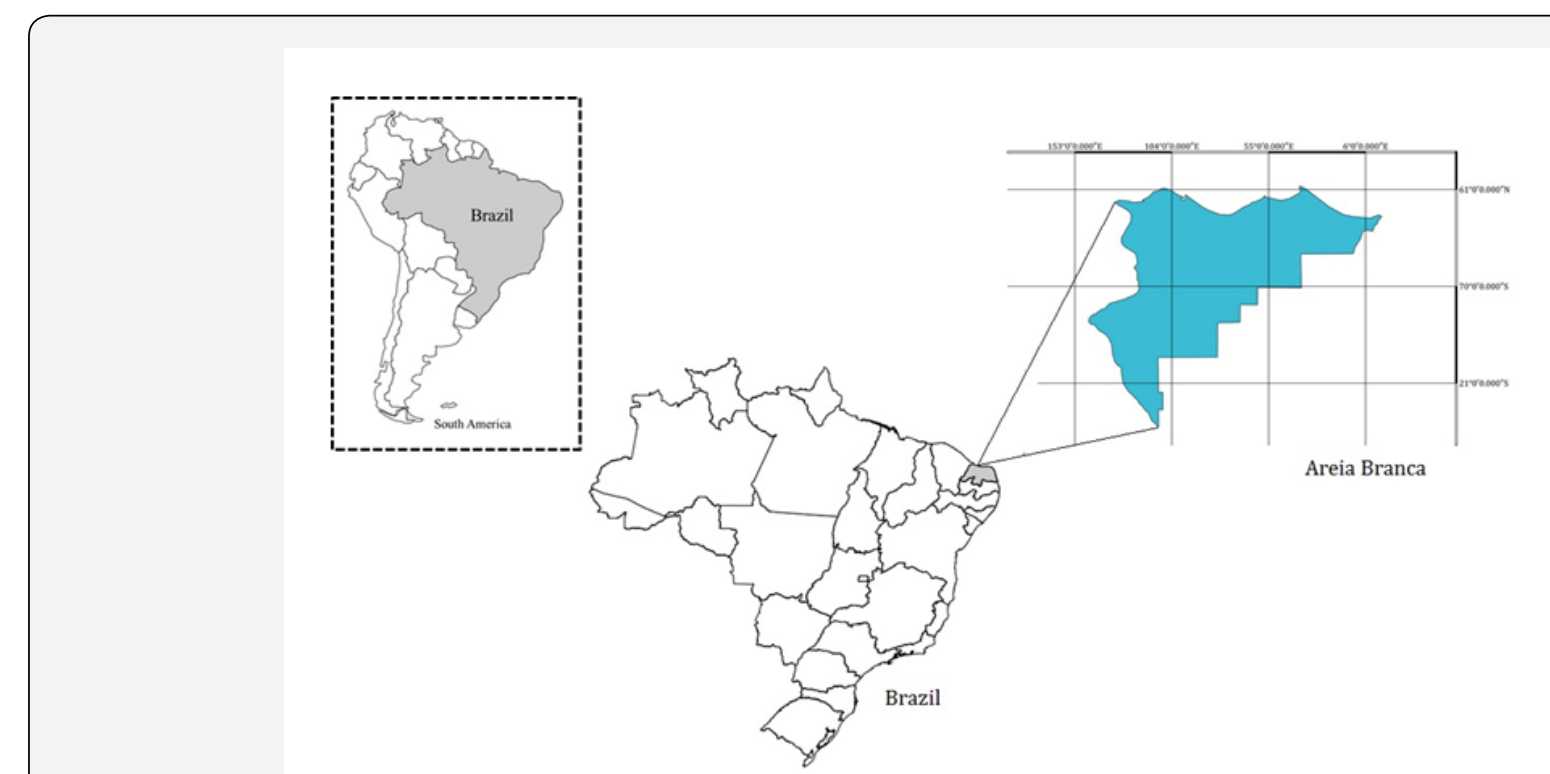

Figure 1: Map of Brazil highlighting the Rio Grande do Norte state (on Southwest Atlantic Ocean) and the sampling site on Areia Branca coast.

All fish were packaged in individual bags and stored in thermal boxes (with ice) for transport to the laboratory, where they were subjected to meristic and morphometric analysis, registering mainly the total weight (WT, in grams) and the length fork (LF, in millimeter) and the species was confirmed and sexed according Vazzoler [12]. After capturing in study area and the realization of biometrics, the fish were necropsied to perform the parasitic investigation.

The collecting of the parasitic fauna was carried out according to each specimen found, following the recommendations of Eiras et al. [8], where the gills of the fish were removed and distributed into vials with formalin 1: 4,000; After resting for an hour in solution, the vials were shaken vigorously and the contents resuspended in $5 \%$ formalin; The gill filaments were carefully shaved with scalpel blades for the removal of parasites present; The integument regions of the body, nasal cavities, mouth were analyzed; The collected specimens were stored in $70 \%$ alcohol.

After initial procedures, copepods fixed in alcohol 70\% were counted. The parasitic ecological indexes were calculated and expressed as Bush et al. [13] \& Silva et al. [11]: Prevalence was determined using the equation of the ratio between the number of hosts infected with one or more individuals of a taxonomic group and the number of hosts examined, expressed by the relation:

$$
\mathrm{P} \%=\frac{\text { total number of infected host }}{\text { total number of examined host }} \times 100
$$

Mean Intensity was determined using the equation of the relationship between the total number of parasites a taxonomic group and number of host species infected with those parasites, expressed by the relationship:

$$
\mathrm{MI}=\frac{\text { total number of parasites }}{\text { total number of infected host }}
$$

Mean Abundance was determined using the equation of the relationship between the total number of parasites a taxonomic group, and the total number of hosts examined (infected and uninfected), expressed by the relation:

$$
\mathrm{MA}=\frac{\text { total number of parasites }}{\text { total number of examined host }}
$$

The parasite species were identified with proposed taxonomic identification keys for the study group. To verify a possible influence of sex and length of the hosts on parasitic prevalence, was carried out analysis Student's t-test at $5 \%$ significance $(\mathrm{p}<0.05)$.

\section{Results}

They were acquired hundred and two fish (n=102) skipjack tuna (Katsuwonus pelamis) between the sampling months 
(December/2015 to November/2016), presented values biometric these according to Table 1 . Among those acquired fish,

it was observed was a predominance of males in the months in study, 54 were males and 48 females.

Table 1: Minimum values ( $\min )$, maximum (max), mean and standard deviation (SD) of biometrics (LF, fork length and WT, total weight) of the population of males and females K. pelamis.

\begin{tabular}{|c|c|c|c|c|}
\hline \multirow[t]{2}{*}{ Values } & \multicolumn{2}{|c|}{ WT (g) } & \multicolumn{2}{|c|}{ LF (mm) } \\
\hline & q & $\hat{0}$ & 우 & 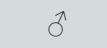 \\
\hline $\min$ & 940.8 & $1,767.0$ & 423 & 450 \\
\hline $\max$ & $5,330.0$ & $10,100.0$ & 700 & 800 \\
\hline mean $\pm S D$ & $2,819.9 \pm 1,019.9$ & $3,625.8 \pm 1,767.7$ & $530 \pm 66$ & $581 \pm 81$ \\
\hline
\end{tabular}

Table 2: Number of parasites $(\mathrm{N})$ prevalence $(\mathrm{P} \%)$, mean intensity $(\mathrm{MI})$, mean abundance $(\mathrm{MA})$ and location of infestation in skipjack tuna in the present study.

\begin{tabular}{|c|c|c|c|c|c|}
\hline Parasites & N & P\% & mI & mA & Location of Infestation \\
\hline Caligus pelamydis & 23 & 17.65 & 1.28 & 0.23 & branchial chamber and body skin \\
\hline Caligus bonito & 61 & 36.27 & 1.65 & 0.60 & branchial chamber and body skin \\
\hline Caligus productus & 49 & 37.25 & 1.29 & 0.48 & branchial chamber \\
\hline Pseudocycnus appendiculatus & 12 & 8.82 & 1.33 & 0.12 & branchial chamber \\
\hline
\end{tabular}

The species copepods parasites were determined using proposed taxonomic identification keys for these species, were identified from their morphological characteristics as Caligus pelamydis (Kroyer, 1863) and C. bonito (Wilson, 1905) parasitizing/located on the branchial chamber and body skin of the host; C. productus (Dana, 1852) and Pseudocycnus appendiculatus (Heller, 1865) parasitizing branchial chamber the host. Ecological indexes of these species infesting skipjack tuna are shown in Table 2. No significant differences were encountered $(\mathrm{P}>0.05)$ of parasitic prevalence between the sexes and sizes of hosts, i.e. there was no significant relationship between these variables.

\section{Discussion}

This study reports the biodiversity and occurrence of parasites copepods parasitizing skipjack tuna (Katsuwonus pelamis) of Rio Grande do Norte coast, northeastern Brazil. According to Carvalho and Luque [14] studies in naturally infected hosts are important for the understanding of population indicators and registration of new hosts and new geographical areas of parasitic species.

In northeastern Brazil, the first record of parasites copepods was made by Schubert in 1936. Subsequently, other researchers have been conducting records of parasite copepods in this region, as Cavalcanti et al. [15] which identified Caligus bonito and Caligus sp. in tainha (Mugil curema) in waters this same region of this study.

The copepods were found in the branchial chambers and integument and can also be located in your nostrils and oral cavity according to other researchers. Parasitic shapes can be constituted up of adults (observed in this work) and some larvae forms, and may be fixed through more or less complex fixation organs, or have some ability to move the surface of the host. The presence of copepods is more or less visible because of the size that can be achieved, or the presence of ovigerous bags whose color often contrasts with the integument of the host, allowing its observation.

Of the species found in this study, Caligus pelamydis, C. bonito, C. productus and Pseudocycnus appendiculatus had previously been cited for this host. Alves et al. [16] in Brazil described this species in Rio de Janeiro \& Mele et al. [10] described these species in skipjack tuna from the western Mediterranean Sea.

The high prevalence of copepods in the analyzed host is common in natural environment, not only to skipjack tuna, but also for other species of fish. According Schalch [5] in habitat in which there is constancy in temperature of the water as water in the Northeast, the seasonal variations of parasitism are not significant. The ecological index of P. appendiculatus (P\%=8.82) in skipjack tuna are down to other works with the same fish that this parasite infested, the prevalence of these ranged from 13 to $13.3 \%$. The C. pelamydis $(\mathrm{P} \%=17.65), C$. bonito $(\mathrm{P} \%=36.27)$ and $C$. productus $(\mathrm{P} \%=37.25)$ are in the same range compared to other work in host $K$. pelamis, the prevalence of these ranged from 13.3 to $80 \%[10,16]$.

Parasitic infections can retard the growth and host weight gain of the fish when they affect food intake [17]. Statistical analysis of the study showed no significant relationship between the ecological indices and the length and weight of the host.

Bullard et al. [18] mentioned that the behavior of forming shoals facilitates the horizontal dispersion of the larvae of copepods in some species of fish, corroborating with the 
ecological parameters of the genus Caligus, pointing out that this behavioral fact, in the present work with skipjack tuna $(K$. Pelamis), influenced the horizontal transmission of parasite species in study. According Appeltans et al. [19] various studies have been conducted over the years to determine the diversity and relative effect of parasitism in the world. However, there is little information on the parasites in skipjack tuna and other species off the coast of Rio Grande do Norte.

\section{Conclusion}

This work made the taxonomic identification of parasitic copepods and recorded the occurrence of Caligus pelamydis, $C$. bonito, C. productus and Pseudocycnus appendiculatus in hostfish Katsuwonus pelamis caught in the Rio Grande do Norte coast. The prevalence of the three parasitic species Caligus ( $C$. pelamydis: $\mathrm{P} \%=17.65$ ) (C. bonito: $\mathrm{P} \%=36.27$ ) (C. productus: $\mathrm{P} \%=37.25)$ were considered normal in relation to other works with the same host under study and P. appendiculatus $(\mathrm{P} \%=8.82)$ was considered low. Location of infestation was the branchial chamber and body skin the host. Compared to other authors study copepods in Rio Grande do Norte, this host-parasite fish presented a diverse flora.

\section{Ethical Approval}

All procedures performed this study involving animals were in accordance with the ethical standards of the institution.

\section{Acknowledgement}

Thanks to Marcia Avelino Coelho for auditing the study. To CNPq (Conselho Nacional de Desenvolvimento Científico e Tecnológico) and CAPES (Coordenação de Aperfeiçoamento de Pessoal de Nível Superior) for financial support granted to postgraduation and graduation programs, and to the UFERSA for technical and scientific support.

\section{Conflict of Interest}

The authors declare no conflict of interests.

\section{References}

1. Thompson JN (1994) The coevolutionary process. Chicago, University of Chicago Press, Illinois, USA.

2. Machado MH, Pavanelli GC, Takemoto RM (1996) Introdução ao estudo dos parasitas de peixes. Apostila. Universidade Estadual de Maringá/ Nupélia, Brazil.

3. Luque JL (2004) Parasitologia de peixes marinhos na América do Sul: estado atual e perspectivas. In: Ranzani-Paiva MJT, Takemoto RM, Lizama MA, Sanidade de organismos aquáticos. São Paulo: Varela, pp. 199-215.

4. Pavanelli GC, Takemoto RM (2000) Aspects of the ecology of proteocephalid cestodes, parasites of Sorubim lima (pimelodidae), of the upper paraná river, brazil: Interspecific associations and distribution of gastrointestinal parasites. Rev Brasil Biol 60(4): 585590.

5. Schalch SHC, Moraes FR, Moraes JRE (2006) Efeitos do parasitismo sobre a estrutura branquial de Leporinus macrocephalus Garavello e Britsk, 1988 (Anastomidae) e Piaractus mesopotamicus Holmberg, 1887 (Osteichthyes: Characidae). Revista Brasileira de Parasitologia Veterinária 15(3): 110-115.

6. Hudson PJ, Dobson AP, Lafferty KD (2006) Is a healthy ecosystem one that is rich in parasites? Trends in Ecology \& Evolution 21: 381-385.

7. Brusca RC, Brusca GJ (2003) Invertebrados. (2 Edn.), Guanabara Koogan, Rio de Janeiro. pp. 568-569.

8. Eiras JC, Takemoto RM, Pavanelli GC (2006) Métodos de Estudo e Técnicas Laboratoriais em Parasitologia de Peixes. (2 Edn.), Rev Amp. Maringá Eduem.

9. Campos CFMD (2006) Fauna parasitária e alterações teciduais em três espécies de peixes dos rios Aquidauana e Miranda, Pantanal Sul Matogrossense. Universidade Estadual Paulista, Centro de Aquicultura pp. 116.

10. Mele S, Macías D, Gómez-Vives MJ, Garippa G, Alemany F, et al. (2012) Metazoan parasites on the gills of the skipjack tuna Katsuwonus pelamis (Osteichthyes: Scombridae) from the Alboran Sea (western Mediterranean Sea). Diseases of aquatic organisms 97(3): 219-225.

11. Silva CG, Figueiredo NC, Martins IX, Lima JTAX (2017) Protozoan Parasite Perkinsus sp. Infecting Crassostrea rhizophorae From the Coast of Rio Grande do Norte (Northeast of Brazil). Journal of Aquaculture \& Marine Biology 6(5): 0166

12. Vazzoler AEAM (1996) Biologia da Reprodução de Peixes Teleósteos: Teoria e Prática. Maringá-PR.

13. Bush AO, Lafferty KD, Lotz JM, Shostak AW (1997) Parasitology meets ecology on its own terms: Margolis et al. revisited. The Journal of Parasitology 83(4): 575-583.

14. Carvalho AR, Luque JL (2009) Ocorrência de Neobenedenia melleni (Monogenea; Capsalidae) em Trichiurus lepturus (Perciformes: Trichiuridae), naturalmente infestados, no litoral do Rio de Janeiro, Brasil. Revista Brasileira de Parasitologia Veterinaria 18(1): 74-76.

15. Cavalcanti ETS, Chellappa S, Pavanelli GC, Takemoto RM (2006) Registro de ocorrência de Caligus bonito e Caligus sp. (copepoda: caligidae) na Tainha, Mugil curema (Osteichthyes: Mugilidae), no litoral de natal, rio grande do norte. Arquivos de Ciências do Mar 39(1-2): 131-133.

16. Alves DR, Luque JL (2006) Ecologia das comunidades de metazoários parasitos de cinco espécies de escombrídeos (Perciformes: Scombridae) do litoral do estado do Rio de Janeiro, Brasil. Revista Brasileira de Parasitologia Veterinária 15(4): 167-181.

17. Bellay S, Ueda BH, Takemoto RM, Lizama MDLAP, et al. (2012) Fauna parasitária de Geophagus brasiliensis (Perciformes: Cichlidae) em reservatórios do estado do Paraná, Brasil. Revista Brasileira de Biociências 10(1): 74.

18. Bullard SA, Goldstein RJ, Hocking R, Jewell J (2003) A new geographic locality and three new host records for Neobenedenia melleni (MacCallum) (Monogenea: Capsalidae). Gulf and Caribbean Research 15(1): 1-4.

19. Appeltans W, Ahyong ST, Anderson G, Angel MV, Artois T, et al. (2012) The magnitude of global marine species diversity. Current Biology 22(23): 2189-2202. 
This work is licensed under Creative

Commons Attribution 4.0 License

DOI: 10.19080/CTBEB.2018.12.555829
Your next submission with Juniper Publishers will reach you the below assets

- Quality Editorial service

- Swift Peer Review

- Reprints availability

- E-prints Service

- Manuscript Podcast for convenient understanding

- Global attainment for your research

- Manuscript accessibility in different formats (Pdf, E-pub, Full Text, Audio)

- Unceasing customer service

Track the below URL for one-step submission https://juniperpublishers.com/online-submission.php 